\title{
The Effects of Immersive Virtual Reality Environments on Students' Academic Achievement: A Meta-analytical and Meta-thematic Study
}

\author{
Muhterem AKGÜN* \\ Institute of Education Sciences, Firat University, Elazı̆̆, Turkey \\ ORCID: 0000-0002-5915-013X \\ Bünyamin ATICI \\ Faculty of Education, Firat University, Elazı̆̆, Turkey \\ ORCID: 0000-0003-0472-0219
}

Article history

Received:

14.04.2021

Received in revised form: 04.10 .2021

Accepted:

02.11.2021

Key words:

Immersive virtual reality,

Meta-analysis,

Meta-thematic,

Academic achievement
The objective of this study is to ascertain the effects of immersive virtual reality environments on students' academic achievement utilizing quantitative and qualitative approaches. First, databases of Web of Science, Google Scholar, ERIC, Proquest, YÖK Thesis Center, and ULAKBIM of Turkey were searched, and 31 studies (23 journal papers and 8 theses) were selected for the meta-analysis. In this context, the overall effect size on students' academic achievement was analyzed with the CMA program using subject area and grade level moderator variables. In the second part, content analysis was performed using the ATLAS.ti program for 8 studies selected for the meta-thematic analysis. it was found that immersive virtual reality environments had a positive, moderate $(\mathrm{d}=0.526)$ effect on students' academic achievement. After the meta-thematic analysis, it was observed that immersive virtual reality environments had many positive effects on students' cognitive, affective, and psychomotor skills and that created a perception of reality and sense of presence in students, facilitates learning, increases motivation, creates a safe and interactive learning environment and make many contributions to learning. In addition, it was determined that there may be problems such as technical problems and health problems during the environments, and it was stated that measures should be taken.

\section{Introduction}

Developing technologies of the 21st century alter learning and teaching environments while they also lead to the advancement of new strategies to increase the effectiveness of these environments. Virtual reality (VR) environments are one of the areas where these technological advancements offer opportunities to enrich learning and teaching environments. The term virtual reality was first used in the 1960s, and its origins went back to the 19th century when the first 360-degree art began to emerge through panoramic murals. Sensorama1 has been a landmark in the evolution of virtual reality with its multi-sensory experience and has been built in several ways that were increasingly close to the physical world (Freina and Ott, 2015). Virtual reality is an environment that gives the person senses of presence and reality (Jayaram,

\footnotetext{
* Correspondency: makgun27@gmail.com
} 
Connacher and Lyons, 1997). VR is a sophisticated human-computer interface that mimics a real-world environment. Subjects can move around in this simulated world and see, reach, capture, and reshape it from different angles (Zheng, Chan, and Gibson, 1998). Virtual reality, according to Kayabaş (2005), is the reconstruction of reality. Pan et al. (2006) define it as it is the use of various graphic systems in order to create an immersive effect in three-dimensional interactive environments. VR is a simulation that creates a realistic-looking environment using computer graphics. It is not a static environment; on the contrary, it responds to and interacts with the user's command inputs. Therefore, interaction is the key term in the definition of virtual reality. Immersion, interactivity, and imagination can be considered as three essential components of virtual reality (Burdea and Coiffet, 2003). Virtual realities are generated through computers and a person can interact with this simulated environment. The person is immersed in this simulated environment where he/she can manipulate objects and perform many actions (UNESCO, 2018).

Virtual reality environments have many contributions to students' cognitive, affective, and psycho-motor skills. In the study by Al-Amri and Musawi (2020) in which the effect of 3D virtual reality environments on the physics lesson of 8th grade students was investigated, it was determined that it had a serious effect on the academic success and motivation of the students. In the study conducted by Kim (2021), it was determined that virtual reality environments had a positive effect on students' academic success and increased their satisfaction levels. As a result of the research conducted by North and North (2016), it was determined that the sense of presence in virtual reality environments is high. Y1ldirım et al. (2020) stated that virtual reality increased students' interest and motivation to the course and provided an individual learning environment for students. As a result of the research conducted by Chien, Hwang and Jong (2020), it was determined that the virtual reality environment increased motivation and critical thinking skills and decreased anxiety, in Akman and Çakır (2020)'s study, it was determined that virtual reality environments increased students' engagement. In the study conducted by Tepe (2019), it was concluded that the virtual reality environment contributed to the learning of the students, increased the permanence, had a high sense of presence, and developed professional skills.

While VR offers a three-dimensional environment, it renders two-dimensional environments obsolete and offers the opportunity to navigate in an unreal environment that we construct (Bayraktar and Kaleli, 2007). Through VR, obstacles between humans and machines are being eliminated to improve human-machine interaction (Kurbanoğlu,1996). This environment has features such as being interactive, attracting students' attention, providing narrative flexibility, being experiential and giving importance to the senses (Çavaş, Huyugüzel Çavaş, and Can Taşkın, 2004). The most significant contribution of VR to instructional settings has been the replacement of printed materials with image and simulation-based content. Virtual reality environments can transform educational environments from isolated textbooks into interactive environments (Helsel, 1992). Virtual reality, which is a motivating, stimulating, and exciting environments that encourages discoveries, can increase students' participation in the learning environment by giving them the feeling of being a part of the learning environment with the sense of presence (Pantelidis, 2010). VR allows students to encounter real-world scenarios that may endanger themselves or others, or where access is potentially limited (Freina and Ott, 2015).

There are many classifications of virtual reality types in the literature. McLellan (1996) mentions 10 types of virtual reality environments: immersive first-person, augmented reality, mirror world, desktop, waldo world, cab simulator environment, chamber world, cyberspace, 
the Vision Dome, and telepresence. Immersive virtual reality is an environment in which many emotions of the user are managed by the virtual environment, which is more isolated from the real world and generally includes head-mounted displays (HMD) (Biocca and Delaney, 1995). Immersive virtual reality environments provide an instant first-person experience (McLellan, 1996). As the immersion increases in virtual environments, the sense of presence also increases (Slater and Sanchez-Vives, 2016).

The literature review revealed that virtual reality environments have been used in several areas including medicine (Crochet et al., 2011; Botden et al., 2007; Lucas et al., 2008), psychiatry (Wiederhold, \& Wiederhold, 2005; Kim et al., 2008; La Paglia et al., 2014), and engineering (Manseur, 2005; Hilfert \& König, 2016). It has been observed that there have been several educational studies in fields such as foreign language (Alfadil, 2017; Legault et al., 2019; Chien, Hwang \& Jong,2020), science (Civelek et al., 2014; Sarığlu \& Girgin, 2020), and STEM (Chen \& Huang, 2019; Lund \& Wang, 2019). Merchant et al. (2014) investigated the effects of games, virtual worlds, and simulations from virtual reality environments on the learning outcomes of K-12 and higher education students through meta-analysis and it was concluded that game-based virtual reality environments were more effective than simulation and virtual worlds. However, there is no study in the literature that evaluates students' learning outcomes of immersive virtual reality environments in terms of meta-analytic and metathematic. Thereupon this research is believed to provide a more holistic and quantitative perspective on how immersive virtual reality environments will contribute to students' academic achievement and to their cognitive, affective and psycho-motor skills, and what kind of difficulties students experience in virtual reality environments.

This study aims to ascertain the effects of immersive virtual reality environments on students' academic achievement and learning environments. Considering these purposes, the research questions of the study were determined as follows:

(1) What is the effect level of immersive virtual reality environments on students' academic achievement?

(2) Does the effect level of immersive virtual reality environments on students' academic achievement differ according to grade level and subject area?

(3) What are the qualitative findings regarding the general characteristics of immersive virtual reality environments in learning environments and their effects on students' cognitive, affective, psycho-motor skills?

\section{Method}

This study employed a mixed-method design to ascertain the effects of immersive virtual reality environments on learning environments and students' academic achievement. The meta-analysis method was used in the quantitative part of the study to establish the effect size of immersive virtual reality environments on students' academic achievement. Meta-analysis provides an overview of individual-level studies through systematically reviewing and quantitatively synthesizing the literature (Petiti, 2001). Rosenthal and Dimatteo (2002) consider meta-analysis as a quantitative summary of the studies with a systematic, evidence-based, repeatable structure. Guzzo, Jackson and Katzell (1987) state that meta-analysis studies are an alternative method that offers more than a systematic review that combines the results of many studies and allows an objective evaluation. Meta-analysis studies have been used in many areas, including education, and the findings of these studies have been effective in determining educational policies in many countries around the world (Borenstein et al., 2011). 
In the qualitative part of the study, meta-thematic analysis was applied to 8 studies that had a qualitative dimension and included participant views between the studies selected the metaanalysis. The meta-thematic analysis is based on document analysis including a verbal/textual analysis process, incorporating qualitative findings by creating new themes and codes by the researcher regarding the investigated studies (Batd1, 2019). As defined by the concept of metathematic analysis, the data of the investigated studies were re-subjected to content analysis, and new themes and codes were created. Content analysis, according to Patton (2018), is the process of reducing and interpreting data by determining the basic consistency and meanings in voluminous qualitative data. The main purpose of content analysis is to combine similar data around certain themes and to make them more understandable (Yıldırım \& Şimşek, 2006). Weber (1990) describes content analysis as the classification and management of textual data by association.

\section{Data Collection}

Firstly, Google Scholar, Web of Science, Education Resources Information Center (ERIC), ProQuest Thesis and Dissertation, The Turkish Council of Higher Education (YÖK) Thesis Center, and The Turkish Academic Network and Information Centre (ULAKBIM) databases were searched, and the studies were examined within the framework of the inclusion/exclusion criteria determined by the researchers. The criteria for inclusion in this study are as follows: Being a thesis study or paper published in refereed journals between 2010 and 2020, being written in Turkish or English, the virtual reality environment used in the study being immersive virtual reality, being an experimental or quasi-experimental study consisting of experimental and control groups, being carried out with parametric tests or providing the information required for meta-analysis (X, ss, $\mathrm{n}$, and so on), and being conducted for educational purposes. Studies conducted in the fields of medicine (surgical procedure, and alike) and psychiatry (for the treatment of autism spectrum, and others) and other types of virtual reality environments (augmented reality, mirror world, and alike) were excluded. The keywords "immersive virtual reality" OR "HMD" AND "teaching" OR "learning" OR "achievement" were searched periodically between 25.12.2020-25.01.2021, studies conducted in the fields of medicine and psychiatry, systematic reviews, and other unrelated studies were excluded by title and abstract review. The summaries of the remaining 107 studies were examined, and 59 studies that did not meet the criteria of being experimental or quasiexperimental design with experimental and control groups, being published in Turkish or English, and having access to the full text were eliminated, and the remaining 48 studies were re-examined. Among these studies, a total of 31 studies were selected for the meta-analysis by eliminating those that were not conducted with parametric tests or did not provide the necessary information for the meta-analysis. Among 31 studies selected for meta-analysis, 8 studies with a qualitative dimension and including participant views were selected for the meta-thematic analysis (Figure 1). 


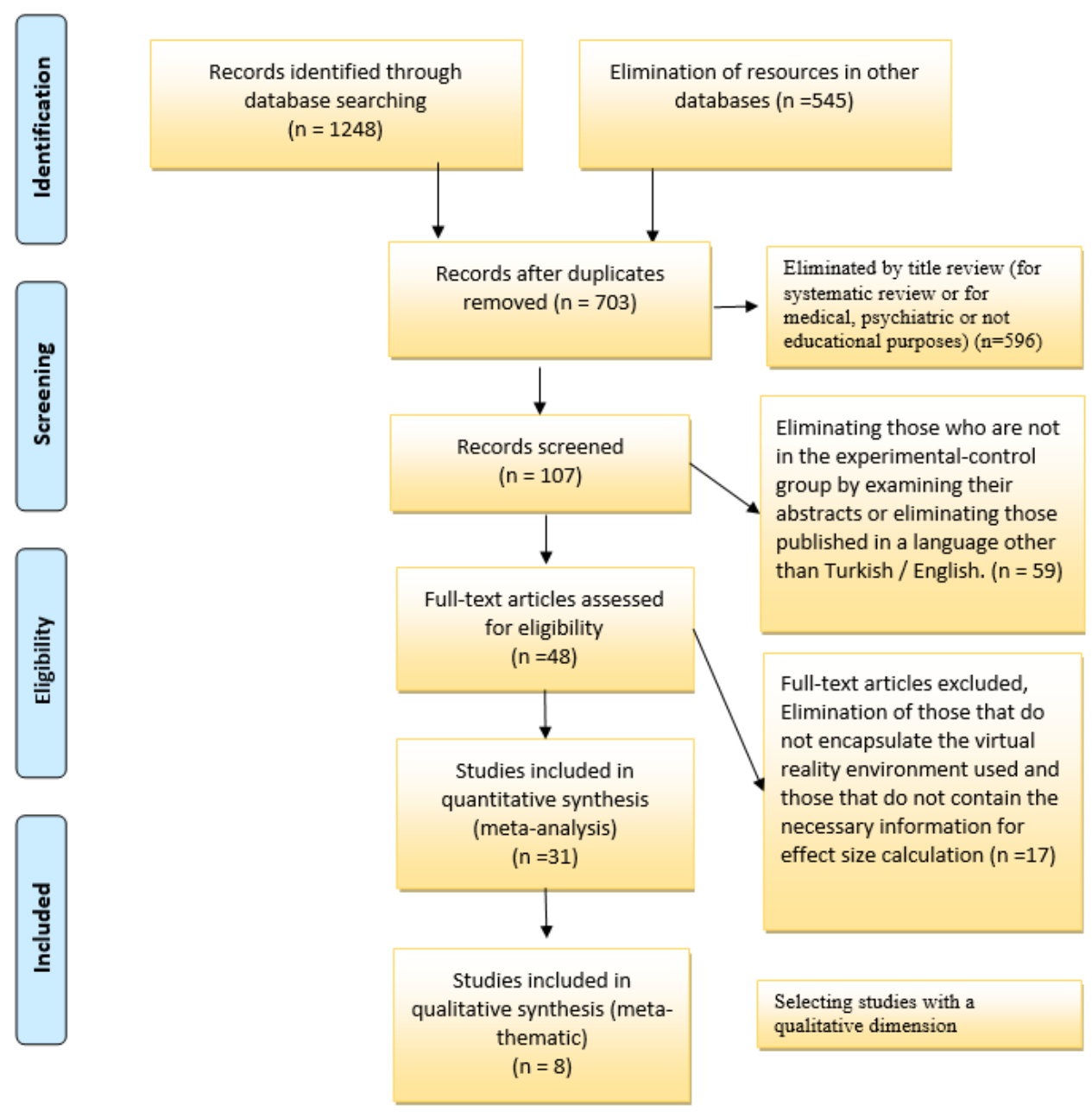

Figure 1. PRISMA Flow Diagram

The 31 studies selected for the meta-analysis consisted of 3 master theses, 5 doctorate dissertations, and 23 journal papers. In the studies produced from theses and published as papers, the journal paper was taken as a reference for meta-analysis. It was detected that 4 of the studies were carried out at elementary school, 9 at secondary school, 3 at high school, and 15 at the university level. In the studies selected for the meta-analysis, the sample size of the experimental group was determined as 1255 and the sample size of the control group as 1312 .

Table1. Information on the studies selected for the meta-analysis

\begin{tabular}{lll}
\hline & Moderator Variables & $\mathrm{n}$ \\
\hline \multirow{3}{*}{ Type of Study } & Master's Thesis & 3 \\
& Doctoral Dissertation & 5 \\
& Journal Paper & 23 \\
\hline \multirow{3}{*}{ Grade Level } & Elementary & 4 \\
& Secondary & 9 \\
& High & 3 \\
\hline Groups & University & 15 \\
\hline Total & $N_{\text {Exp }}$ & 1255 \\
\hline
\end{tabular}




\section{Coding of Data and Reliability of the Study}

A form was created to encode the data related to the studies selected for the metaanalysis. In the first part of this form, information about the name of the author, year of publication, subject area, grade level, and study type was included. In the second part, information about the mean (X), and sample size (n) of the experimental and control groups and standard deviation (sd), required for the effect size was entered. The information in the study review form was checked separately by the researchers and the reliability of the study was calculated as 90\% using Miles and Huberman (1994)'s formula [Consensus / (Consensus + Disagreement). Considering that this ratio should be at least $70 \%$ to ensure the reliability of a study (Yıldırım \& Şimşek, 2006), it was safe to assume that the study was reliable.

The studies selected for the meta-thematic analysis were coded as "P" for journal papers and " $T$ " for theses and direct quotations were presented with the coding page and student code in ATLAS.ti qualitative analysis program. For example, a code in the form of "T5_15-S2" shows the quotation from student $\mathrm{S} 2$ on the 15th code page of the thesis study numbered 5 . In qualitative research, a comprehensive description of how the researcher arrived at the findings and a detailed reporting of the data are important criteria of the validity of the study (Yildirim \& Şimşek, 2006).

\section{Data Analysis}

In this study, the information selected for the meta-analysis study was first entered into the study information form and then analyzed with the Comprehensive Meta-Analysis (CMA) program. Funnel plot and Rosenthal $\mathrm{N}$ theory tests were performed first to see whether there was any publication bias between the studies selected for the meta-analysis. Borenstein et al. (2011) state that the causes of publication bias are incomplete studies, higher probability of publishing studies that give meaningful findings, and inability to include unpublished studies in meta-analysis. Several strategies can be used to detect publication bias and the funnel plot and Rosenthal $\mathrm{N}$ theory are prominent ones. The most popular tool for detecting publication bias in meta-analysis studies is the funnel plot, and the symmetry of the plot with respect to the vertical axis, as well as the presence of an inverted funnel, are accepted as measures of the lack of publication bias in studies (Duval \& Tweedie, 2000). In the funnel plot, studies with a large sample size are collected at the top of the graph, while studies with small samples are distributed in the lower part of the graph (Sterne, Becker \& Egger, 2004). The Rosenthal Safe N Theory assumes that there is a direct proportionality with the distance between the number of studies and the Safe N number (Borenstein et al., 2011).

In a meta-analysis study, a heterogeneous structure is an indication of diversity among the studies (Kulinskaya, Dollinger \& Bjørkestøl, 2011). In this study, the level of heterogeneity between the studies selected for the meta-analysis was determined by comparing the $\mathrm{p}$-value and $Q$ value with the value in Cochran's $X^{2}$ table. At the end of the analysis, it was concluded that there was heterogeneity between the studies, so the effect size calculation was made using the random-effects model. While all studies in the fixed effects model are assumed to have a common parameter, the random-effects model assumes that there are different parameters for each study (Higgins, Thompson \& Spiegelhalter, 2009). The fixed-effects model assumes that all studies in the analysis have a single effect size and that sampling error is the only source of variation for all differences in observed effects. On the other hand, in the random-effects model, while there can be a common effect size for all studies, it is also possible that different studies have different effect size values (Borenstein et al., 2010). This study used Hedge's g for the calculation of effect size values and these values were classified based on Cohen, Manion and 
Morrison (2007) who classified the effect size as weak between 0 and 0.20 , small between 0.21 and 0.50 , medium between 0.51 and 1.00 and strong above 1 .

For the meta-thematic analysis, participant views in 8 studies were subjected to content analysis with the help of the ATLAS.ti program. Yildırım and Şimşek (2006) stated that the qualitative data analysis process consists of data encoding, finding themes, organizing codes/themes, and defining and interpreting the findings. After a detailed examination of the opinions of the participants, themes of general features of the immersive virtual reality environments, the effect of the immersive virtual reality environments on the cognitive/affective/psycho-motor skills, and the problems experienced during the virtual reality environments were determined and codes were created in this context.

\section{Findings and Interpretation}

\section{Findings Regarding Meta-analysis}

\section{Publication bias}

Publication bias is defined as assigning more prominence to studies with significant differences than studies with no significant difference (Sutton et al., 2000) and is an important problem affecting the validity and generalizability of meta-analysis studies (Lin \& Chu, 2018). Therefore, before beginning the meta-analysis study, it should be ensured that there is no publication bias among the selected studies (Dinçer, 2014). One of the ways to achieve this is to use a funnel plot. The symmetry around the vertical axis in a funnel plot is accepted as an indication that there is no publication bias between the studies (Macaskill, Walter \& Irwig, 2001). In a funnel plot, studies with large sample size are collected at the top of the funnel, while studies with small sample size are collected at the bottom of the funnel, and in a plot without publication bias, there is an inverted symmetrical funnel image (Egger at al., 997).

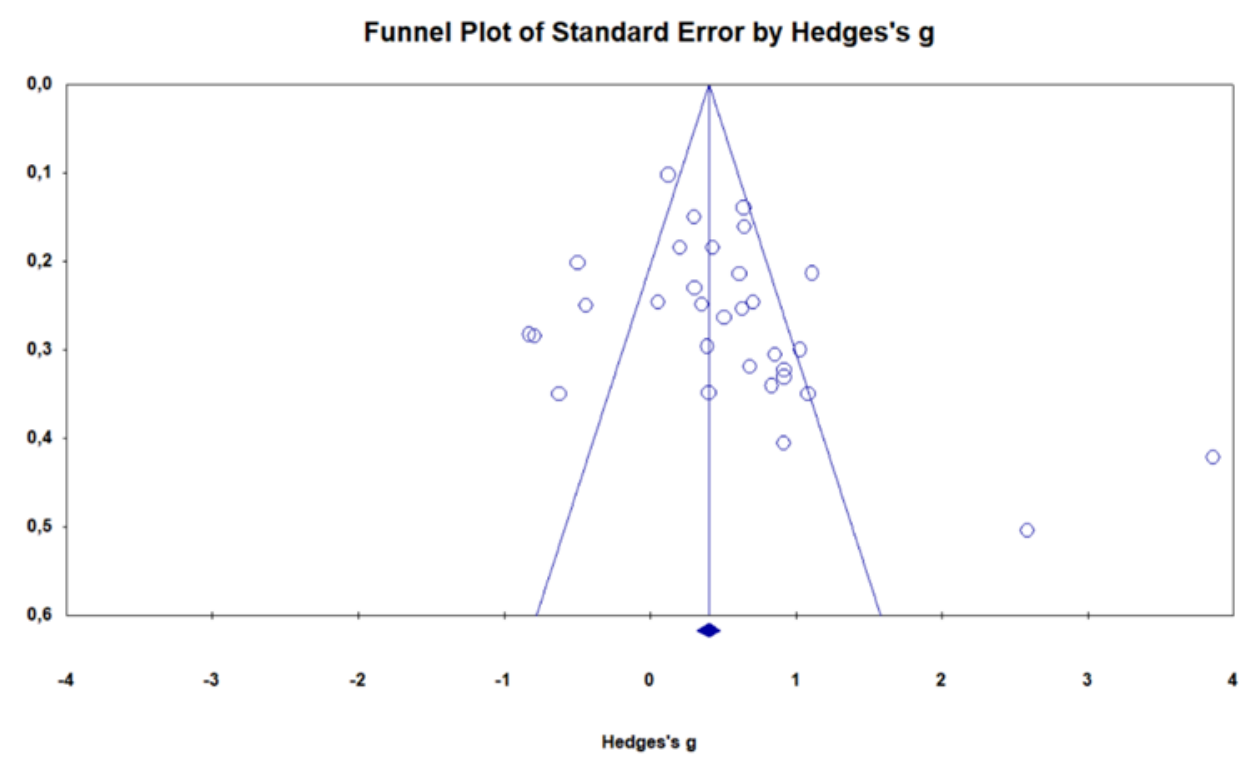

Figure 2. Funnel Plot

In Figure 2, it was observed that the funnel plot was close to being symmetrical around the 
vertical axis and the studies were gathered close to the effect size. Therefore, it could be said that there was no publication bias among the studies selected for the meta-analysis.

However, to make sure that there is no publication bias, other tests can be done, one of which is the Rosenthal Safe N-number test. According to Rosenthal (1984), the Safe N number is expected to be greater than $5 \mathrm{k}+10$ to ensure that there is no publication bias among the studies (cited in Soeken \& Sripusanapan, 2003).

Table 2. Rosenthal Safe N Test for publication bias

\begin{tabular}{ll} 
Z-value for observed studies & 10.88844 \\
p-value for observed Studies & 0.000 \\
Alpha & 0.0500 \\
Tails & 2.00 \\
Z for alpha & 1.95996 \\
Number of observed studies & 31 \\
Number of missing studies that would bring p-value to> alpha & 926.0000 \\
\hline
\end{tabular}

According to Table 2 , the safe $\mathrm{N}$ number $(926>5 * 31+10)$ was far from the number of studies. According to this result, it could be said that there was no publication bias among the studies selected for the meta-analysis.

Table 3. Homogeneity Test

\begin{tabular}{llll}
\hline Q-Value & df $(\mathbf{Q})$ & $\mathbf{p}$ & $\mathbf{I}^{\mathbf{2}}$ \\
\hline 212,689 & 30 & 0.000 & 85,895 \\
\hline
\end{tabular}

If the p-value is less than 0.05 or the $\mathrm{Q}$ value is larger than the value in the $\mathrm{X}^{2}$ table in the homogeneity test, there is heterogeneity between the studies selected for the meta-analysis, and therefore the effect size is calculated using the random-effects model (Petiti, 2001). When the data obtained in this study were examined, heterogeneity was detected between the studies related to the effect of immersive virtual reality environments on academic achievement $(\mathrm{Q}=$ $212,689>53,672 ; \mathrm{p}=0.000<0.05)$. The $\mathrm{I}^{2}$ value $\left(\mathrm{I}^{2}=85 \%\right)$ indicates the heterogeneity level (Huedo-Medina et al., 2006). Also, the difference between the studies included in the metaanalysis is directly proportional to the $\mathrm{I}^{2}$ value (Higgins, 2008).

\section{Overall Effect Size}

Table 4. Effect Size

\begin{tabular}{llllllll}
\hline $\begin{array}{l}\text { Model } \\
\text { Type }\end{array}$ & $\begin{array}{l}\text { Effect Size } \\
(\mathrm{d})\end{array}$ & $\begin{array}{l}\text { Standard } \\
\text { Error }\end{array}$ & Variance & $\begin{array}{l}\text { Lower } \\
\text { Limit }\end{array}$ & $\begin{array}{l}\text { Upper } \\
\text { Limit }\end{array}$ & Z-Value & $\mathrm{p}$ \\
\hline REM & 0.526 & 0.113 & 0.013 & 0.305 & 0.748 & 4.659 & 0.000
\end{tabular}

Since the studies selected for the meta-analysis had a heterogeneous structure, the randomeffects model was utilized for effect size calculation, and it was calculated as $(\mathrm{d}=0.526)$. Based on Cohen et al. (2007)'s classification, the effect size was medium and created a significant difference favoring the experimental group $(\mathrm{Z}=4.659, \mathrm{p}=0.000)$.

\section{Effect Size According to Moderator Variables}

Table 5. The effect size for moderator variables 


\begin{tabular}{|c|c|c|c|c|c|c|c|c|}
\hline & & & & $\begin{array}{ll}\% & 95 \\
\text { Interval }\end{array}$ & onfidence & $\begin{array}{l}\text { Degree of } \\
\text { freedom }\end{array}$ & Heterog & ity Test \\
\hline & & $\mathrm{N}$ & Hedge's g & $\begin{array}{l}\text { Lower } \\
\text { Limit }\end{array}$ & $\begin{array}{l}\text { Upper } \\
\text { Limit }\end{array}$ & \multirow{7}{*}{13} & Qbetween & $\mathrm{p}$ \\
\hline \multirow{6}{*}{ Field } & Science & 6 & 0.363 & 0.272 & 0.999 & & & \\
\hline & STEM & 2 & 0.700 & 0.418 & 0.981 & & & \\
\hline & Foreign Language & 8 & 0.473 & 0.047 & 0.899 & & 70.666 & 0.000 \\
\hline & Mathematics & 3 & 0.156 & 0.765 & 0.454 & & & \\
\hline & Health & 2 & 0.258 & 0.048 & 0.565 & & & \\
\hline & $\begin{array}{l}\text { Occupational } \\
\text { safety }\end{array}$ & 2 & 2.124 & -1.233 & 5.482 & & & \\
\hline & Elementary & 4 & 0.125 & -0.617 & 0.813 & & & \\
\hline $\begin{array}{l}\text { Grade } \\
\text { Level }\end{array}$ & Secondary & 9 & 0.617 & 0.238 & 0.997 & 3 & 9.699 & 0.02 \\
\hline & High & 3 & 0.502 & 0.191 & 0.813 & & & \\
\hline & University & 15 & 0.612 & 0.238 & 0.987 & & & \\
\hline
\end{tabular}

While calculating the effect size based on the subject area, the heterogeneity between the studies was controlled first. Since the value in the $\mathrm{X}^{2}$ table (22.362) corresponding to the $\mathrm{p}(0.000$ $<0.005)$ and degree of freedom $(\mathrm{df}=13)$ is lower than the value of Qbetween $(70.666)$, a heterogeneous structure was detected between the studies. Therefore, a random-effects model has been used. It has been determined that the highest effect size values based on the subject area were in the fields of occupational safety $(d=2.124)$ and STEM $(d=0.700)$. Positive effect sizes were also determined in the fields of foreign language $(d=0.473)$, Science $(d=0.363)$, Mathematics $(d=0.156)$, Health $(d=0.258)$. Although other fields were present in the metaanalysis study, they could not be selected for the comparison based on the subject area, since there were not enough studies.

In the comparison based on students' grade levels, the value in $X^{2}$ table (7.815) corresponding to the $\mathrm{p}(0.02<0.05)$ and the degree of freedom $(\mathrm{df}=3)$ was found to be lower than the value of $\mathrm{Q}$ between (9.699), and therefore effect size was calculated utilizing the random-effects model. It was determined that the highest effect sizes were for secondary school $(\mathrm{d}=0.617)$, university $(d=0.612)$ and high school $(d=0.502)$.

\section{Findings Regarding the Meta-thematic Analysis}

In Figure 3, it was seen that codes such as "creating a perception of reality", "safe learning environment", "removing the time-space limitation", "providing an interactive learning environment" were created regarding the opinions of the participants selected for the metathematic analysis. 


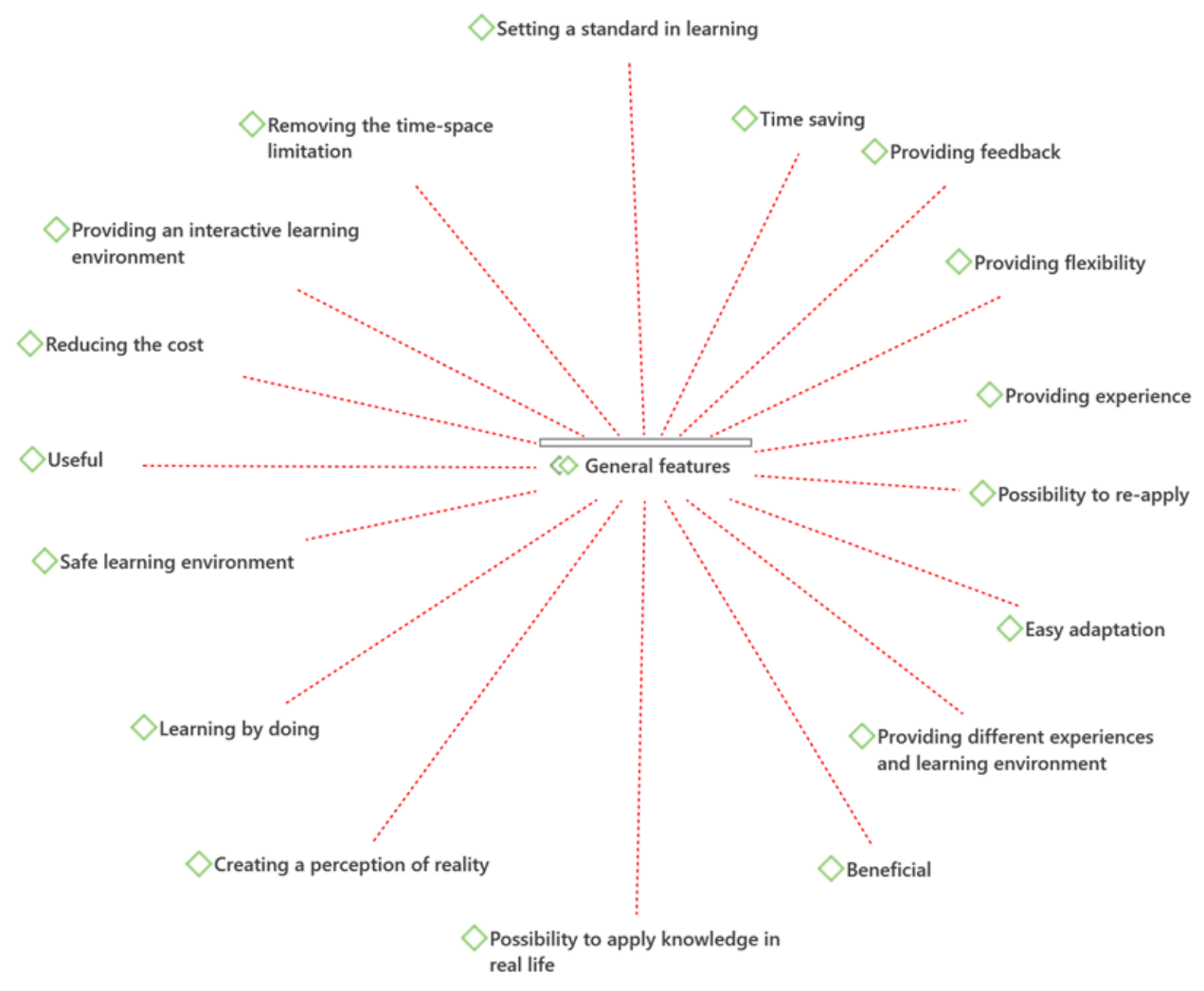

Figure 3. General Features of Immersive Virtual Reality Environments

Some of the student views that were effective in the creation of these codes are as follows:

T3_2-S3: "We really seem to have experienced the incident. When you don't wear the mask, you die. I felt like I was going to fall when I looked down or something. It really looks like real-life drills. I can say that I was fascinated even after taking off the glasses for about half an hour or so", T3_27-S4: "I didn't think it was so realistic. After all, how real can the virtual be... Too realistic, I mean, the body releases adrenaline. It literally wakes up our excitement, emotions, and feelings.", P3_9-S5: "When I wear SVVR, it is just like I am standing on the top of Yu Shan and enjoying its magnificent landscape", P4_10-S2: "I like real-time interaction in the virtual world. In the learning process, I would pause to see the objects, listening to the words or sentences repeatedly. My interaction with people in the virtual world gave me a deeper impression of the learning content...", T2_25-S10: "I'm thinking, get ready, get out of the house, you are at your destination in at least 30 minutes, wait for training, attend training only at certain hours. It is not like that in virtual, I can work 24/7.", T3_22-S1: "With VR we made this practice like the real thing. You feel that you are really in there, you are living it. I think I personally experienced this practice. I learned by feeling", P3_14-S1: "Seeing the authentic images let me have the feeling of virtually being there. This kind of learning interaction facilitated my writing impression and assisted me in recalling the memories in the contexts...". T3_13-S3: "It will help to avoid errors. It prevents the loss of life and property. We can do as many drills as we want. We save time. These environments are catchy and effective". 


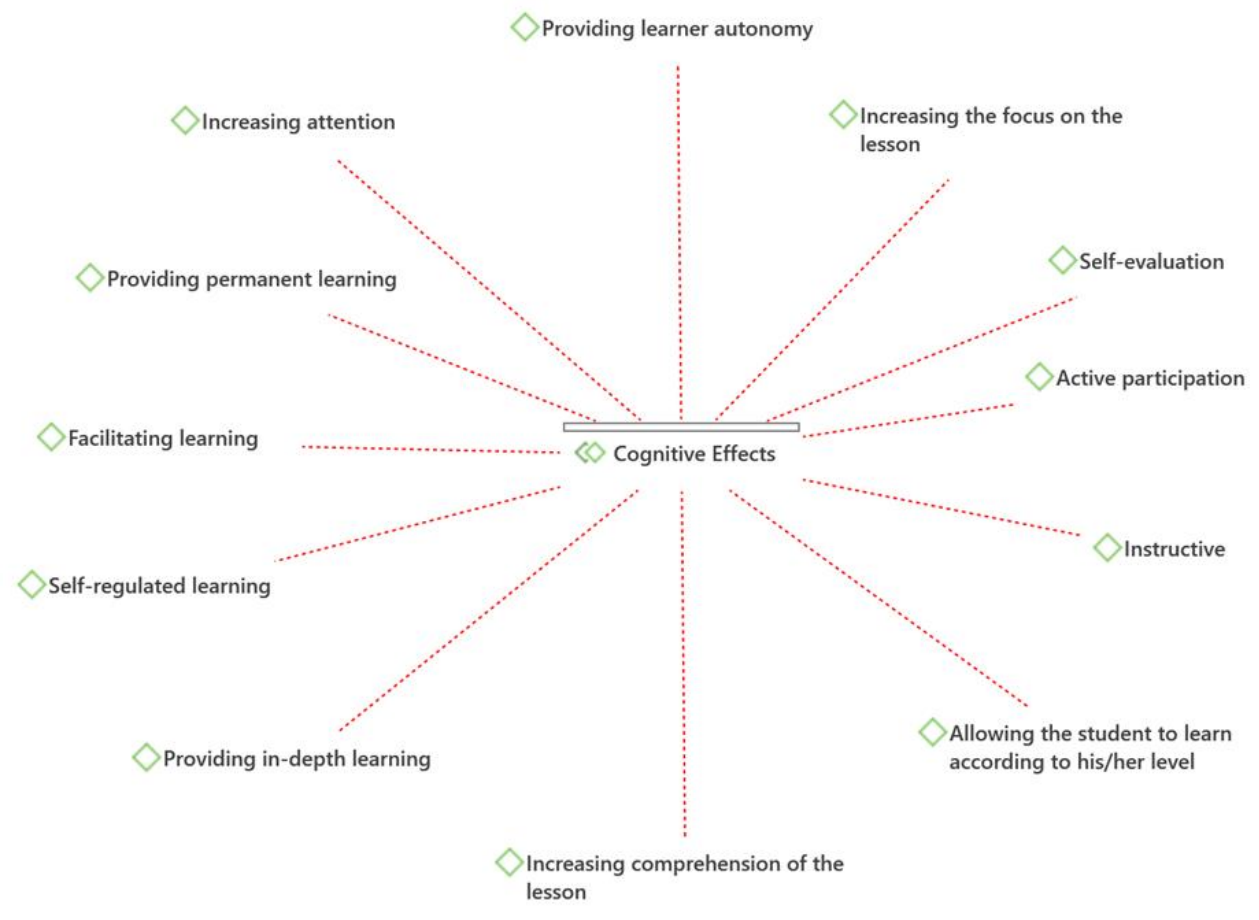

Figure 4. Cognitive Effects of Immersive Virtual Reality Environments

When Figure 4 was examined, among the codes obtained from the data collected from the participants in the studies examined within the scope of meta-thematic analysis, it is seen that codes such as "providing permanent learning", "increasing comprehension of the lesson", "increasing the focus on the lesson", "active participation", "providing in-depth learning", "self-regulated learning", and "allowing the student to learn according to their level" were created. Some of the participant views regarding these codes are as follows:

T3_18-S5: "We easily completed the tasks that we desired in the environments. It is permanent and instructive", P4_10-S2“... My interaction with people in the virtual world gave me a deeper impression of the learning content. I remembered words easier. Although I did not know every word, the context and the virtual characters' body language helped me guess the meaning right", T3_23-S2: "You are constantly writing in theoretical courses. On the other, you are in the fire, trying to help people. There is more active participation", T2_11-S1: "I believe the effects are positive because the person steps out of a certain learning method while learning and learning takes place in a playful setting. I think learning literally takes place", T2_37-S7: "Virtual reality environments was an experience I have never practiced before. I did not get too tired and saved a lot of time because it took me a little time to do a large number of repetitions. It is a great opportunity to be able to choose the level of difficulty and the action I will work on as I want. In this way, I could only concentrate on the area I want to improve.", T2_18-S1: "You can practice whenever you want, as long as you want, in any difficulty; provides great time savings and flexibility". 


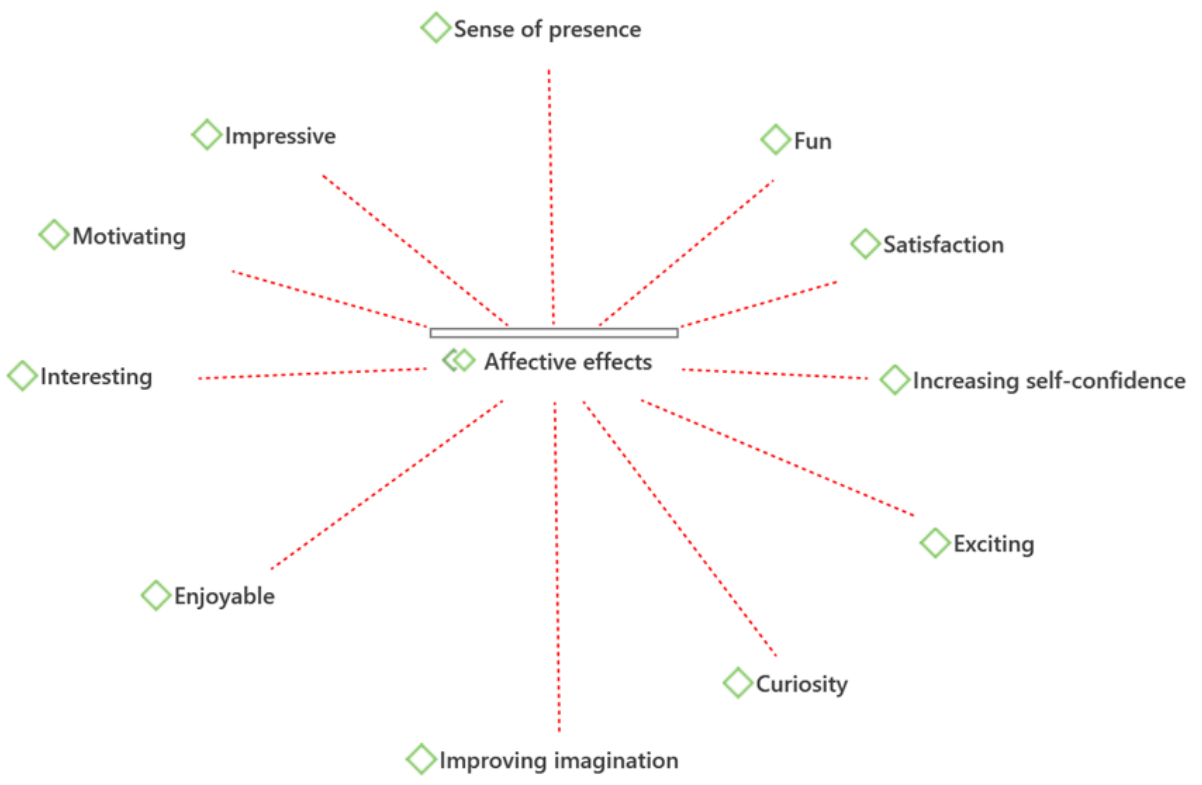

Figure 5. Affective Effects of Immersive Virtual Reality Environments

In Figure 5, it was seen that regarding the affective effects of immersive virtual reality environments, codes such as "sense of presence", "motivating", "exciting", "satisfaction", "interesting", and "increasing self-confidence" were created. Some of the participant views regarding these codes are as follows:

P3_29-S1: "Before using SVVR, I could only try hard to figure out what to write based on my writing ability. I could not understand the author's real perception, either. However, with SVVR, I can have a sense of presence and better realize the mental perceptions of how the author described the on-site landscape. I realize that writing an article can be so touching and I learned some beautiful sentence patterns from the author!", T3_6-S4: "We feel like we are in the action. Thanks to VR, we have calmness because we feel like we are in the environment", T2_20-S10: "Every week, although I did not have a class that day, I ran to school on the day of virtual reality education. First of all, it leaves your troubles aside so that you can only focus your attention on anything but the tool. It offers a reality that you can organize and manipulate as you wish. Just a few seconds after you start using the tool, you forget that the virtual environment is virtual and switch to a completely different world", P4_3-S1: "I like VR because it is interesting, cool, and not tedious. It is like playing computer games. The virtual world is realistic, which motivates me to learn English vocabulary", P1_19-S10: "I used to be afraid that I couldn't speak English well, but after practicing a few times, I was more confident and dared to speak".

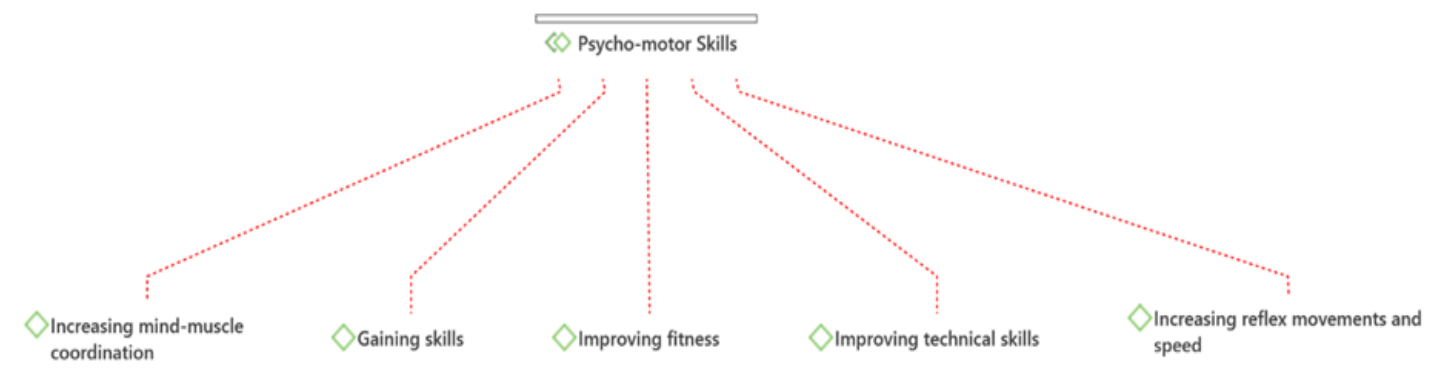

Figure 6. The effect of Immersive Virtual Reality Environments on Psycho-motor Skills 
According to Figure 6, regarding the effect of virtual reality environments on psycho-motor skills, codes such as "improving technical skills", "increasing mind-muscle coordination", "improving fitness" were created. Some of the student views that were effective in the creation of these codes are as follows:

T2_12-S3: "I believe that virtual reality improves reaction, attention, technique, speed, and can improve fitness by increasing training levels.", T2_15: S5: "The angle of arrival, pace, height, and touchpoints of oncoming balls vary in conventional learning. This is ineffective for reworking workouts. This condition appears to be advantageous in virtual reality; I believe you can choose the system based on the angle, pace, height, and point it touches.".

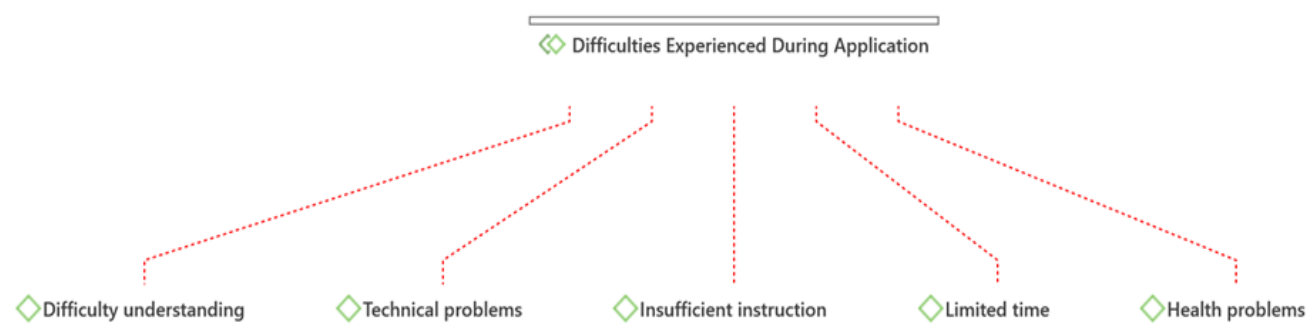

Figure 7. Difficulties Experienced During Immersive Virtual Reality Environments

According to Figure 7, regarding the problems experienced during immersive virtual reality environments codes such as "technical problems", "limited time", "health problems" were created. Participant views regarding these codes are as follows:

T1_1-S8: "It would freeze from time to time, but it was OK...", P1_42-S11: "Except that the volume is sometimes not very clear, I think it is fine on the whole", T1_38-S8: “...There were times when I didn't know what to do in the game... When I saw the boxes in the first part, I did not know what to do ...", P4_16-S2: "I am not good at English. I had to listen, respond, and read the caption simultaneously. Also, I was curious about the objects in the virtual world. I would like to take a look at them. There's not enough time. I did not know how to say some words. I had to listen to these words again and again. Although there was a caption, I did not have enough time to read it thoroughly.", T3_37-S6: "VR glasses should be adjusted for the person's eye. I do not wear glasses, but I had watering eyes when I stayed there for a long time.".

\section{Conclusion and Discussion}

This study was conducted to determine the effects of immersive virtual reality environments on students' academic achievement and learning environments. The study was conducted with a mixed-method design; in the quantitative dimension, 31 studies included in the study based on the criteria determined by the researchers were subjected to meta-analysis, and in the qualitative dimension, 8 studies with a qualitative dimension and participant views were subjected to meta-thematic analysis. For the meta-analysis study, first, whether there was any publication bias between the studies was tested using the funnel plot and Rosenthal's Safe $\mathrm{N}$ theory. When the funnel plot created for the studies selected for the meta-analysis was examined, it was observed that the graph was symmetrical and in the form of an inverted funnel. Moreover, when the Rosenthal Safe $\mathrm{N}$ theory test for publication bias was examined, it was found that the safe $\mathrm{N}$ number $(926>5.31+10)$ was far from the number of studies. Considering these findings, one could say that there was no publication bias among the studies included in the meta-analysis. To determine whether the selected studies were homogeneous, the value 
obtained by comparing the $\mathrm{p}$-value and $\mathrm{Q}$ value with the value in the $\mathrm{X}^{2}$ table was examined. As a result of the examination, a heterogeneous structure was detected between the studies selected for the meta-analysis $(\mathrm{Q}=212,689>53,672 ; \mathrm{p}=0.000<0.05)$. For this reason, the random-effects model was utilized to calculate the general effect size.

In the findings obtained from the study, the general effect size regarding the studies included in the meta-analysis was calculated as (Hedge's $g=0.526$ ). This value was classified as medium (Cohen et al., 2007), and created a significant difference favoring the experimental group ( $\mathrm{Z}=$ $4.659, \mathrm{p}=0.000)$. In their meta-analysis studies on the effect of students' academic achievement, Merchant et al. (2014) and Wu, Yu, and Gu (2020) also found that virtual reality environments had a positive effect on learning. A multitude of studies in the literature reported that virtual reality environments made positive significant differences in students' academic achievement (Kim, 2006; Hwang and Hu, 2013; Merchant et al. 2013; Civelek et al., 2014; Bowen, 2018; Zhou, Xu, \& Wang, 2018; Legault et al., 2019; Shi, Wang \& Ding, 2019; Tepe, 2019; Acar \& Cavaş, 2020; Chen et al., 2020; Liu et al., 2020; Sarığlu \& Girgin, 2020). On the other hand, some studies did not find any significant difference (Davis et al., 2020; Liou et al., 2017; Makransky, Terkildsen \& Mayer, 2019).

It has been found that the highest effect size value based on the subject area was in occupational safety education ( $g=2.124)$ which showed a strong effect according to Cohen et al. (2007)'s classification. In several studies, it has been determined that the occupational safety behavior skills of the students have greatly improved with virtual reality and that most of the students could demonstrate their behavioral skills in real environments (Cha et al., 2012; Xu et al., 2014; Zhang et al., 2017; Çakıroğlu \& Gökoğlu, 2019; Tepe, 2019; Leder et al., 2019; Fu and Li, 2020). Similarly, there have been positive effects determined in the fields of STEM ( $g=0.700)$, foreign language $(g=0.473)$, science $(g=0.363)$, mathematics $(g=0.156)$, and health $(g=0.258)$. When the literature was examined, it was observed that virtual reality environmentss positively affected student success in the field of STEM (El-Mounayri et al., 2016; Chen et al., 2019; Lund \& Wang, 2019). In the study conducted by Bogusevschi et al. (2018) on the effect of immersive virtual reality environments, students found the virtual reality environment very useful and stated that it made learning enjoyable. In the examination based on grade level, it was determined that the highest effect size was for secondary school (Hedge's $g=0.617$ ), university (Hedge's $g=0.612$ ), and high school (Hedge's $g=0.502$ ). This result might be due to the higher number of studies conducted at these grade levels since Wu et al. (2020) reported that virtual reality environments were more effective at the K-12 level.

Regarding the general features of immersive virtual reality environments obtained from the meta-thematic analysis, codes of creating a perception of reality, safe learning environment, removing time-space limitation, providing an interactive learning environment, and learning by doing were created. According to Jayaram, Connacher, and Lyons (1997), virtual reality is the environment that gives a person senses of presence and reality. Pandelidis (2010), on the other hand, states that virtual reality can provide students with a sense of presence and give them the feeling of being a part of the learning environment, thus enabling them to participate in the learning environment. This finding overlaps with the results of other studies in the literature (Hwang \& Hu, 2013; Liou et al., 2017; Tepe, 2019; Akman \& Çakır, 2020; Chien, Hwang \& Jong, 2020; Huang, Hwang \& Chang, 2020; Kalkan, 2020; Tai, Chen \& Todd, 2020).

Regarding the cognitive effects of the immersive virtual reality environments obtained from the meta-thematic analysis, it was seen that codes such as providing permanent learning, increasing the comprehension of the lesson, increasing the focus on the lesson, providing active 
participation, providing in-depth learning, self-regulated learning, and allowing the student to learn according to his/her level were created. This finding is in line with the findings of other research (Hwang \& Hu, 2013; Liou et al., 2017; Fabris et al., 2019; Tepe, 2019; Akman \& Çakır, 2020; Chien, Hwang \& Jong, 2020; Huang et al., 2020; Kalkan, 2020; Tai et al., 2020). In the study of Sakdavong, Burgues, and Huet (2019) on self-regulation in virtual reality environments, it was found that immersive environments and interaction with the environment were very effective on self-regulated learning.

Regarding the affective effects of the immersive virtual reality environments obtained from the meta-thematic analysis, codes such as "sense of presence", "motivating", "exciting", "satisfaction", "interesting", and "increasing self-confidence" were created. As a result of the research conducted by Finkelstein et al. (2011), it was also concluded that virtual reality environments increase students' motivation. In the study investigating teachers' views on the use of virtual reality in STEM education, Yildirım et al. (2020) stated that virtual reality increased students' interest and motivation to the course and provided an individual learning environment for students. Vincent et al. (2008) concluded in their study that immersive virtual reality environments increase students' satisfaction levels and self-efficacy perceptions. Sanchez-Vives and Slater (2005) describe the concept of presence as the phenomenon of acting and feeling as if being in the computer-generated virtual world. Although physically in a different environment, feeling and being active in the virtual reality environment are the fundamental features of virtual reality (Schwind et al., 2019). In the research conducted by Makransky et al., (2019), it was found that immersive virtual reality environments created more sense of presence than others. Other studies in the literature also support this result (Hwang and Hu, 2013; Liou et al., 2017; Tepe, 2019; Akman \& Çakır, 2020; Chien et al., 2020; Huang et al., 2020; Kalkan, 2020; Tai et al., 2020).

In the meta-thematic analysis, it was seen that regarding the effects of immersive virtual reality environments on psycho-motor skills, codes of improving technical skills, increasing mindmuscle coordination, and improving fitness were created. Kalkan (2020) reported that a virtual reality environment could be an effective method in teaching technical skills for playing table tennis. Regarding the problems experienced during virtual reality environments, codes such as technical problems, limited time, health problems were created. In the study conducted by Kaleci, Tepe, and Tüzün (2017) on the opinions of virtual reality users, it was stated that some users experienced negative things such as dizziness, nausea, blurred eyes, insufficient sound in the virtual reality environment, and anxiety. In the research conducted by Demir (2019), it was observed that there were complaints such as dizziness, headache, and fatigue. In the research conducted by Karaoğlan, Yilmaz, and Yilmaz (2019), issues of dizziness and nausea were observed due to graphic and sound incompatibility.

\section{Suggestions}

In light of the results of this study, the following recommendations were made:

- It has been determined that virtual reality environments have a positive effect on students' academic achievement and cognitive, affective, and psychomotor skills. Therefore, immersive virtual reality environments should be used more in learning environments.

- It has been determined that virtual reality environments have a higher level of impact especially in the field of occupational safety and STEM and have a positive effect in fields such as Science, foreign language, and mathematics. Since there are not enough 
studies in some fields such as physics and computers, they could not be included in the meta-analysis based on the subject are. Studies should also be conducted in these areas.

- It has been concluded that virtual reality environments have a higher effect at the secondary school and university levels. However, the number of studies conducted at other educational levels appears to be quite insufficient number wise. Studies at other educational levels are recommended.

- It was concluded that some health and technical problems may be experienced during virtual reality environments. Relevant precautions should be taken accordingly prior to initiating the use of virtual reality environments.

- Limited and insufficient meta-analysis studies were spotted on the effects of virtual reality environments on students' academic achievement. Meta-analysis studies can be conducted for students' academic achievement, sense of presence, and motivation.

- There are a fair number of types of virtual reality environments. However, it has been determined that meta-analysis studies that present a holistic approach to compare the effects of these environments in the literature are insufficient in number. Studies may be conducted to compare different virtual reality environments in the future.

Note: Studies included in the meta-analysis are marked with "*".

\section{REFERENCES}

*Acar, A. \& Cavaş, B. (2020). The Effect of Virtual Reality Enhanced Learning Environment On The 7th-Grade Students' Reading and Writing Skills İn English. Malaysian Online Journal of Educational Sciences, 8(4), 22-33.

*Akbulut, A., Catal, C., \& Y1ld1z, B. (2018). On the effectiveness of virtual reality in the education of software engineering. Computer Environmentss in Engineering Education, 26(4), 918-927.

*Akman, E. \& Çakır, R. (2020): The effect of educational virtual reality game on primary school students' achievement and engagement in mathematics, Interactive Learning Environments, DOI: 10.1080/10494820.2020.1841800

*Alfadil, M. M. (2017). Virtual Reality game classroom implementation: teacher perspectives and student learning outcomes. Unpublished Doctoral Thesis. The University of Northern Colorado.

Al-Amri, A., Osman, M., \& Al Musawi, A. (2020). The Effectiveness of a 3D-Virtual Reality Learning Environment (3D-VRLE) on the Omani Eighth Grade Students' Achievement and Motivation towards Physics Learning. International Journal of Emerging Technologies in Learning, 15(5).

Batd1, V. (2019). Meta-tematik analiz [Meta-thematic Analysis]. V. Batdı (Ed.), Meta-tematik analiz: Örnek uygulamalar in[Meta-thematic analysis sample applications]. (s. 10-76). Ankara: An1 Publication.

Bayraktar, E., \& Kaleli, F. (2007). Sanal gerceklik ve uygulama alanlari[Virtual reality and its environments areas]. Academic Informatics, 1-6.

Biocca, F., \& Delaney, B. (1995). Immersive virtual reality technology. Communication in the age of virtual reality, 15(32), 10-5555.

Bogusevschi, D., Bratu, M., Ghergulescu, I., Muntean, C. H., \& Muntean, G. M. (2018, April). Primary school STEM education: using 3D computer-based virtual reality and experimental laboratory simulation in a physics case study. In Ireland International Conference on Education, IPeTEL workshop, Dublin. 
Borenstein, M., Hedges, L. V., Higgins, J. P., \& Rothstein, H. R. (2010). A basic introduction to fixed-effect and random-effects models for meta-analysis. Research synthesis methods, 1(2), 97-111.

Borenstein, M., Hedges, L. V., Higgins, J. P., \& Rothstein, H. R. (2011). Introduction to metaanalysis. John Wiley \& Sons.

Botden, S. M., Buzink, S. N., Schijven, M. P., \& Jakimowicz, J. J. (2007). Augmented versus virtual reality laparoscopic simulation: what is the difference?. World journal of surgery, 31(4), 764-772.

*Bowen, M. M. (2018). Effect of virtual reality on motivation and achievement of middleschool students. Unpublished Doctoral Thesis. The University of Memphis.

Burdea, G. C., \& Coiffet, P. (2003). Virtual reality technology. John Wiley \& Sons.

Cha, M., Han, S., Lee, J., \& Choi, B. (2012). A virtual reality-based fire training simulator integrated with fire dynamics data. Fire Safety Journal, 50, 12-24.

${ }^{*}$ Chen, J. C., Huang, Y., Lin, K. Y., Chang, Y. S., Lin, H. C., Lin, C. Y., \& Hsiao, H. S. (2020). Developing a hands-on activity using virtual reality to help students learn by doing. Journal of Computer Assisted Learning, 36(1), 46-60.

*Chien, S. Y., Hwang, G. J., \& Jong, M. S. Y. (2020). Effects of peer assessment within the context of spherical video-based virtual reality on EFL students' English-Speaking performance and learning perceptions. Computers \& Education, 146, 103751.

*Civelek, T., Ucar, E., Ustunel, H., \& Aydın, M. K. (2014). Effects of a haptic augmented simulation on K-12 students' achievement and their attitudes towards physics. Eurasia Journal of Mathematics, Science and Technology Education, 10(6), 565-574.

Cohen, L., Manion, L., \& Morrison, K. (2007). Research methods in education. Routledge. https://doi.org/10.4324/9780203029053.

Crochet, P., Aggarwal, R., Dubb, S. S., Ziprin, P., Rajaretnam, N., Grantcharov, T., ... \& Darzi, A. (2011). Deliberate practice on a virtual reality laparoscopic simulator enhances the quality of surgical technical skills. Annals of surgery, 253(6), 1216-1222.

Çakıroğlu, Ü. \& Gökoğlu, S. (2019). Development of fire safety behavioral skills via virtual reality. Computers \& Education, 133, 56-68.

Çavaş, B., Çavaş, P. H., \& Can, B. T. (2004). Eğitimde sanal gerceklik [Virtual reality in education]. TOJET: The Turkish Online Journal of Educational Technology, 3(4).

*Davis, A., Linvill, D. L., Hodges, L. F., Da Costa, A. F., \& Lee, A. (2020). Virtual reality versus face-to-face practice: A study into situational apprehension and performance. Communication Education, 69(1), 70-84.

Demir, R. (2019). Sanal gerçeklik gözlüğüne dayalı din öğretimine yönelik öğretmen adaylarının tutumu [The Attitude of Preservice Teachers' for Religious Teaching Based on Virtual Reality Glasses]. MANAS Journal of Social Research, 8(1), 847-861.

Duval, S. \& Tweedie, R. (2000). Trim and fill: a simple funnel-plot-based method of testing and adjusting for publication bias in meta-analysis. Biometrics, 56(2), 455-463.

Egger, M., Smith, G. D., Schneider, M. \& Minder, C. (1997). Bias in meta-analysis detected by a simple, graphical test. Bmj, 315(7109), 629-634.

El-Mounayri, H., Rogers, C., Fernandez, E., \& Satterwhite, J. C. (2016). Assessment of STEM e-Learning in an immersive virtual reality $(V R)$ environment. Paper presented at 2016 ASEE Annual Conference \& Exposition, New Orleans, Louisiana.

Fabris, C. P., Rathner, J. A., Fong, A. Y., \& Sevigny, C. P. (2019). Virtual Reality in Higher Education. International Journal of Innovation in Science and Mathematics Education, 27(8).

Finkelstein, S., Nickel, A., Lipps, Z., Barnes, T., Wartell, Z., \& Suma, E. A. (2011). Astrojumper: Motivating exercise with an immersive virtual reality exergame. Presence: Teleoperators and Virtual Environments, 20(1), 78-92. 
Freina, L., \& Ott, M. (2015, April). A literature review on immersive virtual reality in education: state of the art and perspectives. In The international scientific conference elearning and software for education (Vol. 1, No. 133, pp. 10-1007).

Fu, Y., \& Li, Q. (2020, April). Immersive Virtual Reality for Fire Safety Behavioural Skills Training via Gesture-based Technology. In IOP Conference Series: Materials Science and Engineering (Vol. 825, No. 1, p. 012015). IOP Publishing.

Guzzo, R. A., Jackson, S. E., \& Katzell, R. A. (1987). Meta-analysis analysis. Research in organizational behavior, $9(1), 407-442$.

Helsel, S. (1992). Virtual reality and education. Educational Technology, 32(5), 38-42.

Higgins, J. P. (2008). Commentary: Heterogeneity in meta-analysis should be expected and appropriately quantified. International journal of epidemiology, 37(5), 1158-1160.

Higgins, J. P., Thompson, S. G., \& Spiegel halter, D. J. (2009). A re-evaluation of randomeffects meta-analysis. Journal of the Royal Statistical Society: Series A (Statistics in Society), 172(1), 137-159.

Hilfert, T., \& König, M. (2016). Low-cost virtual reality environment for engineering and construction. Visualization in Engineering, 4(1), 1-18.

*Huang, H. L., Hwang, G. J., \& Chang, C. Y. (2020). Learning to be a writer: A spherical video-based virtual reality approach to supporting descriptive article writing in high school Chinese courses. British Journal of Educational Technology, 51(4), 1386-1405.

Huedo-Medina, T. B., Sánchez-Meca, J., Marín-Martínez, F., \& Botella, J. (2006). Assessing heterogeneity in meta-analysis: Q statistic or $\mathrm{I}^{2}$ index?. Psychological methods, 11(2), 193.

*Hwang, W. Y., \& Hu, S. S. (2013). Analysis of peer learning behaviors using multiple representations in virtual reality and their impacts on geometry problem solving. Computers \& Education, 62, 308-319.

Jayaram, S., Connacher, H. I., \& Lyons, K. W. (1997). Virtual assembly using virtual reality techniques. Computer-aided design, 29(8), 575-584.

Kaleci, D., Tepe, T. ve Tüzün, H. (2017). Üç Boyutlu Sanal Gerçeklik Ortamlarindaki Deneyimlere Ilişkin Kullanici Görüşleri [User Views on Experiences in Three Dimensional Virtual Reality Environments]. Turkey Social Studies Journal, 21(3), 669689.

*Kalkan, N. (2020). Temel Teknik Beceri Öğretiminde Sanal Gerçeklik Teknolojisinin Etkililiğinin Incelenmesi: Masa Tenisi Örneği [Investigation of the Effectiveness of Virtual Reality Technology in Basic Technical Skills Teaching: Table Tennis Example]. Unpublished Dotoral Thesis. Manisa Celal Bayar University. Health Sciences Institute. Manisa.

Karaoğlan Yılmaz, F. G. ve Yılmaz, R. (2019). Sanal gerçeklik uygulamalarının eğitimde kullanımına ilişkin ögretmen adaylarının görüşlerinin incelenmesi [Examining the opinions of pre-service teachers on the use of virtual reality environmentss in education]. III. International Congress on Science and Education. Afyonkarahisar.

Kayabaşı, Y. (2002). Sanal Gerçeklik ve Eğitim Amaçlı Kullanılması [Use for Virtual Reality and Educational Purposes]. Turkish Online, 151.

Kim, K., Kim, C. H., Cha, K. R., Park, J., Han, K., Kim, Y. K., ... \& Kim, S. I. (2008). Anxiety provocation and measurement using virtual reality in patients with obsessivecompulsive disorder. Cyber Psychology \& Behavior, 11(6), 637-641.

*Kim, P. (2006) Effects of 3D virtual reality of plate tectonics on fifth grade students' achievement and attitude toward science, Interactive Learning Environments, 14:1, 2534, DOI: $10.1080 / 10494820600697687$

Kim, M. H. (2021). Effects of Collaborative Learning in a Virtual Environment on Students' Academic Achievement and Satisfaction. Journal of Digital Convergence, 19(4), 1-8. 
*Koçbuğ, R. (2018). The Effectiveness of Virtual Reality on Vocabulary Learning and Retention. (Unpublishes Master Thesis). İstanbul University. Institute of Education Sciences.

Kulinskaya, E., Dollinger, M. B., \& Bjørkestøl, K. (2011). Testing for homogeneity in metaanalysis I. The one-parameter case: standardized mean difference. Biometrics, 67(1), 203-212.

Kurbanoğlu, S. (1996). Sanal gerçeklik: Gerçek mi, değil mi? [Virtual reality: Real or not]. Turkish Librarianship.10(1), 21-31

La Paglia, F., La Cascia, C., Cipresso, P., Rizzo, R., Francomano, A., Riva, G., \& La Barbera, D. (2014, May). Psychometric assessment using classic neuropsychological and virtual reality based test: A study in obsessive-compulsive disorder (OCD) and schizophrenic patients. In International Symposium on Pervasive Computing Paradigms for Mental Health (pp. 23-32). Springer, Cham.

*Leder, J., Horlitz, T., Puschmann, P., Wittstock, V., \& Schütz, A. (2019). Comparing immersive virtual reality and powerpoint as methods for delivering safety training: Impacts on risk perception, learning, and decision making. Safety science, 111, 271286.

*Legault, J., Zhao, J., Chi, Y. A., Chen, W., Klippel, A., \& Li, P. (2019). Immersive virtual reality as an effective tool for second language vocabulary learning. Languages, 4(1), 13.

Lin, L., \& Chu, H. (2018). Quantifying publication bias in meta-analysis. Biometrics, 74(3), 785-794.

*Liou, H.-H., Yang, S. J. H., Chen, S. Y., \& Tarng, W. (2017). The Influences of the 2D ImageBased Augmented Reality and Virtual Reality on Student Learning. Educational Technology \& Society, 20 (3), 110-121.

*Liu, R., Wang, L., Lei, J., Wang, Q., \& Ren, Y. (2020). Effects of an immersive virtual realitybased classroom on students' learning performance in science lessons. British Journal of Educational Technology, 51(6), 2034-2049.

Lucas, S. M., Zeltser, I. S., Bensalah, K., Tuncel, A., Jenkins, A., Pearle, M. S., \& Cadeddu, J. A. (2008). Training on a virtual reality laparoscopic simulator improves performance of an unfamiliar live laparoscopic procedure. The Journal of urology, 180(6), 2588-2591.

*Lund, Brady D. and Wang, Ting (2019) "Effect of Virtual Reality on Learning Motivation and Academic Performance: What Value May VR Have for Library Instruction?," Kansas Library Association College and University Libraries Section Proceedings: Vol. 9: No. 1. https://doi.org/10.4148/2160-942X.1073

Macaskill, P., Walter, S. D., \& Irwig, L. (2001). A comparison of methods to detect publication bias in meta-analysis. Statistics in medicine, 20(4), 641-654.

*Makransky, G., Terkildsen, T. S., \& Mayer, R. E. (2019). Adding immersive virtual reality to a science lab simulation causes more presence but less learning. Learning and Instruction, 60, 225-236.

Manseur, R. (2005, October). Virtual reality in science and engineering education. In Proceedings Frontiers in Education 35th Annual Conference (pp. F2E-8). IEEE.

McLellan, H. (1996). Virtual realities. Handbook of Research for Educational Communications and Technology (pp. 457-487). Boston: Kluwer-Nijhoff Publishing.

Merchant, Z., Goetz, E. T., Cifuentes, L., Keeney-Kennicutt, W., \& Davis, T. J. (2014). Effectiveness of virtual reality-based instruction on students' learning outcomes in K12 and higher education: A meta-analysis. Computers \& Education, 70, 29-40.

*Merchant, Z., Goetz, E. T., Keeney-Kennicutt, W., Cifuentes, L., Kwok, O. M., \& Davis, T. J. (2013). Exploring 3-D virtual reality technology for spatial ability and chemistry achievement. Journal of Computer Assisted Learning, 29(6), 579-590. 
Miles, M. B., \& Huberman, A. M. (1994). Qualitative data analysis: An expanded sourcebook (2nd ed.). Thousand Oaks: Sage Publications.

North, M. M., \& North, S. M. (2016). A Comparative Study of Sense of Presence of Traditional Virtual Reality and Immersive Environments. Australasian Journal of Information Systems, 20. https://doi.org/10.3127/ajis.v20i0.1168

Pan, Z., Cheok, A. D., Yang, H., Zhu, J., \& Shi, J. (2006). Virtual reality and mixed reality for virtual learning environments. Computers \& graphics, 30(1), 20-28.

Pantelidis, V. S. (2010). Reasons to use virtual reality in education and training courses and a model to determine when to use virtual reality. Themes in Science and Technology Education, 2(1-2), 59-70.

Patton, M.Q (2018). Nitel Araştırma ve Değerlendirme Yöntemleri [Qualitative Research and Evaluation Methods] (Çev. Ed.: Mesut BÜTÜN and Selçuk Beşir DEMİR). Pegem Akademi: Ankara

Petitti, D. B. (2001). Approaches to heterogeneity in meta-analysis. Statistics in medicine, 20(23), 3625-3633.

Rosenthal, R., \& Di Matteo, M. R. (2002). Meta-analysis. Stevens' handbook of experimental psychology.

Sakdavong, J. C., Burgues, M., \& Huet, N. (2019, May). Virtual Reality in Self-regulated Learning: Example in Art Domain. In CSEDU (2) (pp. 79-87).

Sanchez-Vives, M. V., \& Slater, M. (2005). From presence to consciousness through virtual reality. Nature Reviews Neuroscience, 6(4), 332-339.

*Sarioglu, S. \& Girgin, S. (2020). The Effect of Using Virtual Reality in 6th Grade Science Course the Cell Topic on Students' Academic Achievements and Attitudes Towards the Course. Journal of Turkish Science Education, 17 (1), 109-125.

Schwind, V., Knierim, P., Haas, N., \& Henze, N. (2019, May). Using presence questionnaires in virtual reality. In Proceedings of the 2019 CHI conference on human factors in computing systems (pp. 1-12).

*Selzer, M. N., Gazcon, N. F., \& Larrea, M. L. (2019). Effects of virtual presence and learning outcome using low-end virtual reality systems. Displays, 59, 9-15.

*Shi, A., Wang, Y., \& Ding, N. (2019). The effect of game-based immersive virtual reality learning environment on learning outcomes: designing an intrinsic integrated educational game for pre-class learning. Interactive Learning Environments, 1-14.

Slater, M., \& Sanchez-Vives, M. V. (2016). Enhancing our lives with immersive virtual reality. Frontiers in Robotics and AI, 3, 74.

*Smith, S. J., Farra, S. L., Ulrich, D. L., Hodgson, E., Nicely, S., \& Mickle, A. (2018). Effectiveness of two varying levels of virtual reality simulation. Nursing education perspectives, 39(6), E10-E15.

Soeken, K. L., \& Sripusanapan, A. (2003). Assessing publication bias in meta-analysis. Nursing research, 52(1), 57-60.

Sterne, J. A., Becker, B. J., \& Egger, M. (2005). The funnel plot. Publication bias in metaanalysis: Prevention, assessment and adjustments, 75-98.

Sutton, A. J., Song, F., Gilbody, S. M., \& Abrams, K. R. (2000). Modelling publication bias in meta-analysis: a review. Statistical methods in medical research, 9(5), 421-445.

*Tai, T. Y., Chen, H. H. J., \& Todd, G. (2020). The impact of a virtual reality app on adolescent EFL learners' vocabulary learning. Computer Assisted Language Learning, 1-26.

*Tepe, T. (2019). Başa Takllan Görüntüleyiciler İçin Geliştirilmiş Sanal Gerçeklik Ortamlarının Ögrrenme ve Buradalı Algisl Üzerine Etkilerinin Incelenmesi [Investigating The Effects of Virtual Reality Environments Developed for HeadMounted Display on Learning and Presence]. (Unpublished Doctoral Thesis). Hacettepe University. Institute of Education Sciences. Ankara 
*Topuz, Y. (2018). Anatomi eğitiminde sanal gerçeklik ve üç boyutlu masaüstü materyallerin akademik başarı ve bilişsel yük açısından karşılaştırılması [Comparison of virtual reality and 3D desktop materials in terms of academic achievement and cognitive load in anatomy education]. Unpublished master Thesis, Marmara University, Institute of Education Sciences, İstanbul.

UNESCO (2018). UNESCO ICT Competency Framework for Teachers.

Vincent, D. S., Sherstyuk, A., Burgess, L., \& Connolly, K. K. (2008). Teaching mass casualty triage skills using immersive three-dimensional virtual reality. Academic Emergency Medicine, 15(11), 1160-1165.

*Wang, T. (2017). The effect of virtual reality on learning motivation and academic performance. Unpublished mastery thesis. Emporia State University.

Weber, R. P. (1990). Basic content analysis (No. 49). Sage.

Wiederhold, B. K., \& Wiederhold, M. D. (2005). Virtual reality therapy for anxiety disorders: Advances in evaluation and treatment. American Psychological Association.

Wu, B., Yu, X. \& Gu, X. (2020). Effectiveness of immersive virtual reality using head-mounted displays on learning performance: A meta-analysis. British Journal of Educational Technology, 51(6), 1991-2005.

Xu, Z., Lu, X. Z., Guan, H., Chen, C., \& Ren, A. Z. (2014). A virtual reality based fire training simulator with smoke hazard assessment capacity. Advances in engineering software, $68,1-8$.

Yıldırım, A., \& Şimşek, H. (2006). Sosyal Bilimlerde Nitel Araştırma Yöntemleri [Qualitative research methods in the social sciences]. Seçkin Publication: Ankara

*Yildirim, B., Sahin-Topalcengiz, E., Arikan, G., \& Timur, S. (2020). Using virtual reality in the classroom: Reflections of STEM teachers on the use of teaching and learning tools. Journal of Education in Science, Environment and Health (JESEH), 6(3), 231-245. DOI:10.21891/jeseh.711779

Zhang, K., Suo, J., Chen, J., Liu, X., \& Gao, L. (2017, September). Design and implementation of fire safety education system on campus based on virtual reality technology. In 2017 Federated Conference on Computer Science and Information Systems (FedCSIS) (pp. 1297-1300). IEEE.

Zheng, J. M., Chan, K. W., \& Gibson, I. (1998). Virtual reality. Ieee Potentials, 17(2), 20-23.

*Zhou, Y., Ji, S., Xu, T., \& Wang, Z. (2018). Promoting knowledge construction: a model for using virtual reality interaction to enhance learning. Procedia computer science, 130, 239-246. 